\title{
ING4 Gene
}

National Cancer Institute

\section{Source}

National Cancer Institute. ING4 Gene. NCI Thesaurus. Code C150264.

This gene is involved in acetylation of histone $\mathrm{H} 3$ and histone $\mathrm{H} 4$. 